\title{
INTERNALISASI NILAI PENDIDIKAN KARAKTER MELALUI METODE PEMBELAJARAN CONTEXTUAL TEACHING AND LEARNING DAN PEMBIASAAN MEMBACA AL-QUR'AN UNTUK MENANGKAL PENGARUH KEMAJUAN TEKNOLOGI INFORMASI DAN KOMUNIKASI DI TINGKAT SEKOLAH DASAR
}

\author{
Sarafuddin \\ Universitas Slamet Riyadi \\ e-mail : Sarafuddinmj11@gmail.com
}

\begin{abstract}
This study aims to get a clear picture of (1) Strategies to internalize the value of character education through CTL learning methods and the habit of reading the Qur'an to counteract the development of information and communication technology in 3 Public Elementary Schools and solo high schools, and (2)) The CTL learning method and the habit of reading the Qur'an can counteract the development of information and communication technology in 3 public elementary and private high schools. This study included descriptive qualitative research, with a single fixed case study strategy. Data obtained from: (1) Places and events namely learning activities in 3 Public Elementary Schools and private solo schools ;; (2) Documents, namely documents containing textbooks, methods and learning strategies used by the teacher, and reports on student learning evaluation results, and (3) Informants, consisting of PKn subject teachers, local transportation subject teachers and students in 3 Public Elementary Schools and private solo schools. To obtain data is done by (1) Observation; (2) Document analysis, and (3) In-depth interviews. The targets of this study include; (1) Add insight to teachers in choosing learning methods that can understand students about the development of communication and information, and (2) Provide separate learning methods in an effort to internalize the value of character education to students to counteract the development of information and communication technology using the Contextual Teaching and learning methods Learning (CTL) and the habit of reading the Qur'an.

Key words: Character Education, CTL and Reading the Al-Qur'an,
\end{abstract}

\begin{abstract}
Abstrak
Penelitian ini bertujuan untuk mendapatkan gambaran yang jelas tentang: (1) Strategi untuk menginternalisasikan nilai pendidikan karakter melalui metode pembelajaran CTL dan pembiasaan membaca Al Qur'an untuk menangkal pengaruh kemajuan teknologi informasi dan komunikasi di 3 SD Negeri dan swasta solo raya, dan (2) Metode pembelajaran CTL dan pembiasaan membaca Al Qur'an dapat menangkal pengaruh kemajuan teknologi informasi dan komunikasi di 3 SD Negeri dan swasta solo raya. Penelitian ini termasuk penelitian deskriptif kualitatif, dengan strategi studi kasus terpancang tunggal. Data diperoleh dari: (1) Tempat dan peristiwa yaitu kegiatan pembelajaran di 3 SD Negeri dan swasta solo raya.; (2) Dokumen, yaitu dokumen berupa buku-buku pelajaran, metode dan strategi pembelajaran yang digunakan oleh guru, dan laporan hasil evaluasi belajar siswa, dan (3) Informan, yaitu terdiri dari guru mata pelajaran PKn, guru mata pelajaran muatan lokal dan siswa di 3 SD Negeri dan swasta solo raya. Untuk memperoleh data dilakukan dengan: (1) Observasi; (2) Analisis dokumen, dan (3) Wawancara mendalam. Target luaran penelitian ini antara lain; (1) Menambah wawasan guru dalam memilih metode pelajaran yang berbasis pendidikan karakter serta dapat memahamkan
\end{abstract}


siswa tentang pengaruh kemajuan teknologi informasi dan komunikasi, dan (2) Tersedia seperangkat metode pembelajaran dalam upaya internalisasi nilai pendidikan karakter pada siswa untuk menangkal pengaruh kemajuan teknologi informasi dan komunikasi dengan menggunakan metode pembelajaran Contextual Teacing and Learning (CTL) dan pembiasaan membaca Al Qur'an.

Kata Kunci: Pendidikan Karakter, CTL dan Membaca Al-Qur'an,

\section{PENDAHULUAN}

Kebijakan pemerintah Indonesia di bidang pendidikan nampak terlihat belum mencapai target maksimal sebagaimana yang diamanat di dalam UUD 1945 atau bisa dikatakan masih pada tahap mencari bentuk atau pola yang tepat untuk mencapai tujuan pendidikan nasional yang telah ditetapkan. Kondisi ini dibuktikan dengan sering terjadinya pergantian kurikulum yang berlaku secara universal pada setiap jenjang pendidikan. Sebagai produk dari kebijakan pemerintah Indonesia di bidang pendidikan era 10 tahun terakhir ini salah satunya adalah KTSP dan kurikulum 2013. Pada hakekatnya kedua kurikulum ini lebih menekankan aspek keseimbangan antara softskills dan hardskills, lebih-lebih kurikulum 2013. Realita di lapangan dapat dikatakan bahwa belum semua guru sekolah dasar memiliki pengalaman mengajar menggunakan pendekatan pembelajaran tematik integratif. Oleh karena itu, guru harus mampu menginternalisasikan nilai pendidikan karakter dengan membuat variasi pembelajaran yang memadukan metode pembelajaran Contextual Teaching and Learning (CTL) dengan pembiasaan membaca Al-Qur'an. Dengan cara ini dapat menunjukkan peran pendidikan sebagai perubahan (agen of change), yaitu menjaga generasi sejak kecil dari berbagai penyelewengan, mempengaruhi jiwa dan perkembangan anak, dan sebagai alat untuk menjaga diri dan memelihara nilai positif.

Pendidikan karakter berpijak pada karakter dasar manusia yang bersumber dari nilai moral universal (bersifat absolut) agama, yang disebut juga sebagai the golden rule. Kemajuan zaman dengan berbagai kemudahan akses teknologi, jika tidak dibarengi dengan nilai karakter yang kuat akan terjadi kemerosotan moral bangsa.
Karakter bangsa tergantung dari kualitas sumber daya manusia (SDM), maka dari itu perlu dibentuk dan dibina untuk mencapai kualitas karakter yang baik. Furqon (2010: 15) mengatakan bahwa karakter adalah ciri khas yang dimiliki oleh suatu benda atau individu. Pendidikan disekolah tidak hanya mengajar peserta didik membaca, menulis, berhitung dan lulus ujian, akan tetapi harus ada penanaman nilai atau karakter pada peserta didik. Pendidikan karakter memiliki tujuan meningkatkan mutu penyelenggaraan dan hasil pendidikan di sekolah yang mengarah pada penacapaian karakter dan akhlak mulia peserta didik secara utuh, terpadu dan seimbang sesuai dengan standart kompetensi lulusan.

Upaya internalisasi nilai pendidikan karakter pada siswa juga tidak bisa terlepas dari peran teknologi informasi dan komunikasi (TIK) terutama dalam kegiatan belajar mengajar. Pemanfaatan TIK menjadi sebuah keniscayaan dan mutlak digunakan karena sudah menjadi media penghubung yang efektif dan efisien. Di tengah perjalanan waktu yang begitu cepat, pemanfaatan media TIK tidak hanya dapat diakses oleh guru, namun siswapun dapat memanfaatkannya, sehingga dapat berpengaruh terhadap perubahan sikap mental dan pola belajar peserta didik. Berdasarkan fenomena ini muncul pertanyaan bagaimana strategi untuk menginternalisasikan nilai pendidikan karakter melalui metode pembelajaran Contextual Teacing and Learning (CTL) dan pembiasaan membaca $\mathrm{Al}$ Qur'an untuk menangkal pengaruh kemajuan teknologi informasi dan komunikasi di 3 SD Negeri dan swasta solo raya?, dan apakah metode pembelajaran Contextual Teacing and Learning (CTL) dan pembiasaan membaca $\mathrm{Al}$ Qur'an dapat menangkal pengaruh kemajuan 
teknologi informasi dan komunikasi di 3 SD Negeri dan swasta solo raya?.

\section{Luaran Penelitian}

Dari hasil penelitian ini diharapkan dapat memberikan sumbangan pemikiran tentang pentinya pemahaman guru terhadap internalisasi nilai pendidikan karakter pada siswa dengan menggunakan 2 metode pembelajaran yang berbeda yaitu metode pembelajaran Contextual Teacing and Learning (CTL) dan pembiasaan membaca Al Qur'an. Setelah dilaksanakan penelitian yang mendalam, maka luaran yang diinginkan adalah menambah wawasan guru dalam memilih metode pelajaran yang berbasis pendidikan karakter serta dapat memahamkan siswa tentang pengaruh kemajuan teknologi informasi dan komunikasi. Tersedia seperangkat metode pembelajaran dalam upaya internalisasi nilai pendidikan karakter pada siswa untuk menangkal pengaruh kemajuan teknologi informasi dan komunikasi dengan menggunakan metode pembelajaran Contextual Teacing and Learning (CTL) dan pembiasaan membaca $\mathrm{Al}$ Qur'an.

\section{KAJIAN TEORI}

Menurut Abdul Majid (2013: 5) bahwa pembelajaran adalah suatu konsep dari dua dimensi kegiatan (belajar dan mengajar) yang harus direncanakan dan diaktualisasikan, serta diarahkan pada pencapaian tujuan atau penguasaan sejumlah kompetensi dan indikatornya sebagai gambaran hasil belajar. Kegiatan pembelajaran berupaya mengubah masukan kepada siswa yang belum terdidik menjadi siswa yang terdidik, siswa yang belum memiliki pengetahuan menjadi siswa yang memiliki pengetahuan. Pembelajaran adalah suatu proses untuk mengetahui semua hal dari tidak tahu menjadi tahu, kemudian kegiatan pembelajaran dapat dilakukan kapan saja dan dimana saja tidak mengenal waktu dan ruang asalkan dengan niat yang kuat untuk mau mempelajari sesuatu ilmu dengan baik. Ahmad Susanto (2013: 4) bahwa pembelajaran adalah suatu aktivitas yang dilakukan seseorang dengan sengaja dalam keadaan sadar untuk memperoleh suatu konsep, pemahaman, atau pengetahuan baru sehingga memungkinkan seseorang terjadinya perubahan perilaku yang relatif tetap baik dalam berfikir, merasa, maupun dalam bertindak.

Seiring dengan laju perkembangan dunia pendidikan, pendidikan karakter menjadi isu sentral dalam pembelajaran di Indonesia. Segenap komponen pembelajaran dikaitkan dengan elemen pendidikan karakter disebabkan munculnya keluhan semakin menurunnya karakter masyarakat seiring pekembangan zaman. Secara umum pendidikan karakter adalah suatu sistem penanaman nilai-nilai karakter kepada warga sekolah yang meliputi komponen pengetahuan, kesadaran atau kemauan, dan tindakan untuk melaksanakan nilai-nilai tersebut, baik terhadap Tuhan Yang Maha Esa (TYME), diri sendiri, sesama, lingkungan, maupun kebangsaan sehingga menjadi manusia insan kamil (Triatmanto, 2010). Penerapan pendidikan karakter memerlukan kerjasama seluruh komponen pembelajaran untuk keberhasilannya. Dalam pendidikan karakter di sekolah, semua komponen pendidikan (stakeholders) harus dilibatkan, termasuk komponen-komponen pendidikan itu sendiri.

Karakter mengandung nilai-nilai dasar yang bersifat menyeluruh (universal), yang ingin diwujudkan dalam bersikap dan bertingkah laku, serta kompetensi yang perlu dikembangkan dan direalisasikan. Ida Zusnani (2012: 170) menyatakan bahwa nilainilai dasar yang perlu dikembangkan diantaranya: keadilan, kebenaran, kebijaksanaan, kejujuran, keberadaban, kesetaraan, kesejahteraaan, ketaqwaan, keimanan, kesabaran, keikhlasan, amanah, kasih sayang, kebersamaan, kepatuhan, pengendalian diri, tenggang rasa, gotong royong, kepedulian, serta menjauhi sifat iri dan dengki. Proses pembentukan nilai pada anak dapat dikelompokkan dalam 5 tahap, yakni: (1) tahap receiving (menyimak); (2) tahap responding (menanggapi); (3) tahap valuing (memberi nilai); (4) tahap organization (mengorganisasikan), dan (5) tahap characterization (karakterisasi nilai). Berkaitan dengan strategi internalisasi nilai pendidikan karakter pada peserta didik dapat dilakukan melalui 
program pendidikan dan memerlukan dukungan penuh dari pemerintah. Sebagaimana pendapat M. Noor Rohinah (2012: 115) bahwa pendidikan karakter di sekolah dapat diimplementasikan dengan 7 cara, yaitu: (1) diajarkan melalui permodelan, suasana dan kurikulum; (2) datang dari rumah, komunitas dan sekolah; (3) adalah jalan proaktif mengadaptasi dan menggunakan materi pendidikan yang sudah ada untuk meningkatkan pemahaman dan menginspirasi ciri karakter yang baik disemua siswa di setiap bagian pengalaman belajar mereka; (4) adalah didasari hubungan dan budaya sekolah; (5) adalah proses, bukan hanya program; (6) yang terbaik adalah, perubahan (reformasi) sekolah, dan (7) didasari riset, teori dan lebih penting lagi adalah keterlibatan guru dan siswa.

Selanjutnya, upaya internalisasi nilai pendidikan karakter melalui metode pembelajaran CTL dan pembiasaan membaca Al Qur'an untuk menangkal pengaruh kemajuan teknologi informasi dan komunikasi dapat dilakukan dengan kegiatan pembiasaan seperti membaca burhani, muraja'ah, sholat dhuhur berjamaah, tahfidz Al Qur'an, dan baca tulis Al Qur'an. Aris Shoimin, (2014: 83) mengatakan bahwa pembiasaan (Habit Forming) merupakan bagian dari model pembelajaran yang konsisten dan terprogram. Adapun langkahlangkah pembiasaan sebagai berikut: (a) pembiasaan pada anak didik biasanya dilakukan secara terus menerus dan dibutuhkan seseorang untuk contoh atau teladan, dan (b) guru harus mengajak dan bersama-sama melakukan pekerjaan ini. Pembiasaan membaca Al-Qur'an adalah termasuk mata pelajaran muatan lokal di dua sekolah dasar yaitu MIM Gonilan dan MIM Tanjung Sari. Mata pelajaran muatan lokal merupakan kegiatan kurikuler untuk mengembangkan kompetensi yang disesuaikan dengan ciri khas dan potensi daerah. Substansi muatan lokal ditentukan oleh satuan pendidikan, tidak terbatas pada mata pelajaran keterampilan.

Semakin pesatnya kemajuan teknologi informasi dan komunisasi di era global saat ini cenderung mempengaruhi sikap, mental, dan karakter manusia termasuk peserta didik di tingkat sekolah dasar. Secara umum teknologi informasi berarti suatu ilmu mendapatkan hingga menyebarluaskan informasi. Informasi tersebut dapat diolah didalam sistem teknologi agar menghasilkan data yang dapat diterima orang lain. Deni Darmawan (2012: 16) mengatakan bahwa teknologi informasi adalah studi atau penggunaan alat-alat elektronika, terutama komputer untuk menyimpan, menganalisis, dan mendistribusikan informasi apa saja, termasuk kata, bilangan dan gambar. Informasi dapat diciptakan atau dikembangkan melalui proses identifikasi dan penggalian dari sumber-sumber informasi yang terkait. Informasi-informasi tersebut dapat diidentifikasi dan digali beberapa informasi lainnya melalui berbagai cara seperti instrument penelitian, kegiatan eksperiment, pengadaan kuesioner, wawancara dan kegiatan-kegiatan lainnya.

Berdasarkan pendapat di atas dapat dikatakan bahwa guru harus memiliki pemahaman terhadap internalisasi nilai pendidikan karakter pada siswa paling tidak menggunakan 2 metode pembelajaran yang berbeda yaitu metode pembelajaran Contextual Teacing and Learning (CTL) dan pembiasaan membaca Al Qur'an. Di samping itu, guru juga harus mampu menginternalisasikan nilai pendidikan karakter dengan membuat variasi pembelajaran yang memadukan metode pembelajaran Contextual Teaching and Learning (CTL) dengan pembiasaan membaca Al-Qur'an. Dengan cara ini dapat menunjukkan peran pendidikan sebagai perubahan (agen of change), yaitu menjaga generasi sejak kecil dari berbagai penyelewengan, mempengaruhi jiwa dan perkembangan anak serta menjadi alat untuk menjaga dan memelihara nilai positif pada diri anak.

\section{METODE PENELITIAN}

Penelitian ini dilaksanakan di 3 SD Negeri dan swasta solo raya dengan sumber informan adalah guru mata pelajaran PKn, guru mata pelajaran muatan lokal dan siswa. Tempat ini dipilih karena disamping muda terjangkau, baik dari segi biaya maupun waktu dan jarak. Lokasi ini pada dasarnya 
belum maksimal memanfaatkan berbagai metode dan strategi pembelajaran dalam penyampaian materi di setiap mata pelajaran, lebih-lebih mata pelajaran PKn dan mata pelajaran muatan lokal. Penelitian ini adalah penelitian pendidikan dengan pendekatan deskriptif kualitatif yang diharapkan akan mampu menangkap berbagai informasi kualitatif. Di sampaing itu, data yang dikumpulkan berupa kata-kata dan bukan angka-angka, di mana semua data yang dikumpulkan kemungkinan menjadi kunci terhadap objek yang akan diteliti. Kondisi objek sama sekali tidak dijamah oleh perlakuan (treatment) yang dikendalikan secara ketat atau sepenuhnya oleh peneliti seperti halnya di dalam penelitian eksperimental (Sutopo, 2006: 37). Di sini peneliti berfungsi sebagai penggali informasi pada saat berlangsungnya kegiatan penelitian. Strategi penelitian yang digunakan adalah studi kasus tunggal terpancang, sebagaimana pendapat Yin yang dikutip Sutopo (2006: 39) disebut embedded research. Kasus tunggal karena sasaran penelitian ini pada satu kasus yaitu peran ibu dalam mensukseskan pendidikan formal anak. Terpancang karena masalah sudah ditentukan terlebih dahulu sebelum kegiatan penelitian ini dilakukan.

Data penelitian ini diperoleh dari: (1)

Tempat dan peristiwa yaitu kegiatan pembelajaran di 3 SD Negeri dan swasta solo raya. Dari sumber data ini akan diperoleh informnasi tentang internasilasi nilai pendidikan karakter melalui metode pembelajaran Contextual Teaching and Learning (CTL) dan pembiasaan membaca Al-Qur'an; (2) Dokumen, yaitu dokumen berupa buku-buku pelajaran, metode dan strategi pembelajaran yang digunakan oleh guru, dan laporan hasil evaluasi belajar siswa, dan (3) Informan, yaitu terdiri dari guru mata pelajaran PKn, guru mata pelajaran muatan lokal dan siswa di 3 SD Negeri dan swasta solo raya. Dari sumber data ini akan diperoleh informasi tentang: (a) strategi untuk menginternalisasikan nilai pendidikan karakter melalui metode pembelajaran CTL dan pembiasaan membaca Al Qur'an, dan (b) metode pembelajaran CTL dan pembiasaan membaca Al Qur'an dapat menangkal pengaruh kemajuan teknologi informasi dan komunikasi. Untuk memperoleh data dilakukan dengan: (1) Observasi saat pembelajaran berlangsung di kelas; (2) Analisis dokumen, dan (3) Wawancara mendalam. Kemudian dalam upaya memperoleh validitas data dilakukan dengan trianggulasi data/sumber dan metode. Sedangkan teknik analisis data dilakukan secara bersama dengan pengumpulan data secara interaktif dengan model siklus, di mana dalam analisis data ada tiga komponen analisis, yaitu reduksi data, sajian data dan verifikasi atau penarikan simpulan.

\section{HASIL PENELITIAN \\ 1. Deskripsi Latar \\ a. Kondisi Umum Sekolah}

Berdasarkan lingkup wilayah dalam rancangan penelitian ini, yaitu sekolah dasar di Solo Raya yang difokuskan pada 3 SD negeri dan swasta antara lain SD Negeri Prawit I nomor 69 Surakarta, Madrasah Ibtidaiyah Muhammadiyah Gonilan Kartasura Sukoharjo, dan Madrasah Ibtidaiyah Muhammadiyah Tanjung Sari Banyudono Boyolali, maka dapat disajikan kondisi sekolah secara umum terutama pada aspek pembelajaran. Aspek pembelajaran yang dikaji adalah pembelajaran pendidikan karakter.

Berdasarkan hasil observasi dan wawancara dengan guru dan siswa kelas V SD Negeri Prawit I nomor 69 Surakarta, bahwa dalam kegiatan belajar mengajar guru masih menggunakan metode ceramah. Melaui metode mengajar yang digunakan ini, dapat mengakibatkan peserta didik kurang aktif dan tidak memperhatikan guru pada saat penyampaian materi pembelajaran sehingga berdampak pada kesulitan peserta didik menerima isi materi pembelajaran. Di samping itu, peserta didik merasa bosan dan mengantuk saat kegiatan belajar mengajar berlangsung. Kondisi ini berpengaruh terhadap sikap peserta didik yang dinilai masih rendah sebagaimana diskripsi sikap pada mata pelajaran PKn. Sesuai skala penilaian sikap menunjukkan bahwa peserta didik belum mencapai indoktor rata-rata, sehingga dapat dikatakan bahwa sikapnya masih tergolong rendah. Berdasarkan data yang diperoleh peneliti, bahwa pada tahun 
pelajaran 2017/2018 menunjukkan hasil sikap dari peserta didik pada mata pelajaran PKn masih rendah karena proses kegiatan belajar mengajar masih bersifat teacher centered.

Sementara kondisi umum Madrasah Ibtidaiyah Muhammadiyah Gonilan Kartasura Sukoharjo yang didirikan tahun 1960 pada awalnya menempati rumah penduduk. Dalam perkembangan selanjutnya atas upaya keras para pendirinya memotivasi masyarakat sekitar agar ikhlas mewakafkan tanah miliknya untuk didirikan bangunan Madrasah Ibtidaiyah Muhammadiyah (MIM). Secara singkat, dalam perkembangan berikutnya MIM Gonilan mendapatkan tanah wakaf seluas 400 meter persegi. Dari realita di atas, menunjukkan bahwa MIM Gonilan mendapat dukungan yang sangat kuat dan kontinu dari masyarakat muslim di sekitarnya, bukan hanya sekedar dukungan moril tetapi juga dukungan matril. Sebagai bukti dari dukungan masyarakat yaitu selama bertahun-tahun sampai saat ini biaya operasional diambil dari kumpulan infaq masyarakat. Dalam hal menghimpun dana infaq setiap bulan, pengurus madrasah membentuk Majlis Infaq. Dana yang terkumpul didestribusikan untuk biaya operasional madrasah seperti gaji guru dan tata usaha, sarana dan prasarana pembelajaran, dan operasinal lainnya.

Sedangkan kondisi umum di Madrasah Ibtidaiyah Muhammadiyah (MIM) Tanjung Sari Banyudono Boyolali terhadap dampak Teknologi Informasi dan Komunikasi (TIK) memiliki respon yang cukup tinggi. Indikatornya adalah para peserta didik sangat antusias menyimak penjelasan tentang pengaruh buruk dari kemajuan TIK yang yang disampaikan oleh peneliti. Seluruh isi materi mengenai penanaman karakter melalui peran dan fungsi handpon dan gadget direspon positif juga oleh peserta didik yang terfokus di kelas 4 dan sekaligus dijadikan sebagai responden. Berdasarkan hasil observasi tentang karakter peserta didik kelas 4 tersebut, menunjukkan bahwa adanya kesadaran yang baik tentang pemanfaat alat-alat dan hasil teknologi. Kemudian dari hasil analisis antara dampak TIK dan karakter peserta didik kelas 4 MIM Tanjung Sari memperlihatkan adanya hubungan timbal balik antara pemanfaatan TIK dengan perkembangan karakter peserta didik. Kondisi ini terlihat bahwa hampir ratarata peserta didik dapat menggunakan atau memanfaatkan hasil teknologi tersebut di atas untuk keperluan peningkatan kompetensi pendidikannya seperti dalam hal mengerjakan tugas pembelajaran baik dikerjakan di sekolah maupun di rumah.

\section{b. Internalisasi Nilai Pendidikan Karakter Melalui Metode Pembelajaran \\ CTL dan Pembiasaan Membaca Al- Qur'an}

Sebagai seorang pendidikan, maka guru mengupayakan agar peserta didik mengetahui konsep nilai pendidikan karakter. Untuk mengetahui tingkat kepahaman peserta didiknya terhadap pendidikan karakter, maka guru dapat melakukannya melalui tes awal dengan metode tanya jawab sesuai dengan konsep yang menjadi tujuan pembelajaran. Pendidikan karakter dapat dilakukan dengan mendemonstrasikan berbagai kegiatan pembiasaan yang sudah diprogramkan oleh sekolah dan kemudian menugaskan peserta didiknya untuk mempraktikkan materi yang sudah diajarkan guru. Apabila guru yakin bahwa peserta didik telah mampu melaksanakan pembiasaan dengan baik, maka tujuan aspek doing dalam pendidikan karakter sudah tercapai. Sedangkan aspek Being dapat ditunjukkan dari tindakan peserta didik yang telah mampu melaksanakan pembiasaan sebagaimana program yang canangkan sekolah dalam realita kehidupan sehari-hari dan telah menyatu dalam kepribadiannya.

Internalisasi nilai pendidikan karakter dapat dilakukan melalui penggunaan metode pembelajaran yang berorientasi pada nilai karakter dengan beberapa tahapan teknik internalisasi sederhana yaitu: (1) tahap transformasi; (2) tahap transaksi nilai atau komunikasi dua arah, dan (3) tahap transinternalisasi. Dari ketiga tahapan di atas, dapat dikatakan bahwa semua pelaksanaan kegiatan pengintegrasian pendidikan karakter dilingkungan sekolah dapat dilakukan melalui keteladanan, kegiatan spontan, teguran, pengkondisian lingkungan dan kegiatan rutin.

Selanjutnya strategi pembelajaran CTL merupakan strategi pembelajaran yang menekankan kepada proses keterlibatan peserta didik secara penuh untuk dapat menemukan materi yang dipelajari dan 
menghubungkannya dengan situasi kehidupan nyata sehingga mendorong mereka untuk dapat diterapkan dalam kehidupannya. Kemudian strategi pembelajaran ini juga dapat digunakan untuk mengefektifkan dan menyukseskan pendidikan karakter di sekolah. Dengan kata lain, CTL dapat dikembangkan menjadi salah satu strategi pembelajaran berkarakter karena dalam pelaksanaanya lebih menekankan pada keterkaitan antara materi pembelajaran dengan kehidupan nyata peserta didik sehingga mampu menghubungkan dan menerapkan kompetensi hasil belajar dalam kehidupan sehari-hari.

\section{Sajian Data}

Untuk menjelaskan internalisasi nilai pendidikan karakter melalui metode pembelajaran contextual teaching and learning dan pembiasaan membaca al-qur'an untuk menangkal pengaruh kemajuan teknologi informasi dan komunikasi di tingkat sekolah dasar dapat dilihat pada sajian data di bawah ini:

a. Strategi untuk menginternalisasikan nilai pendidikan karakter melalui metode pembelajaran CTL dan pembiasaan membaca Al Qur'an untuk menangkal pengaruh kemajuan teknologi informasi dan komunikasi di 3 SD Negeri dan swasta solo raya

Berdasarkan hasil pengamatan di MIM Gonilan bahwa strategi untuk menginternalisasikan nilai pendidikan karakter pada peserta didik dapat dilakukan melalui pembiasaan membaca Al Qur'an dengan metode burhani. Menurutnya, metode burhani adalah suatu metode percepatan membaca Al Qur'an dengan ketepatan huruf yang dibaca dan sesuai dengan tajwidnya. Strategi internalisasi nilai pendidikan karakter pada peserta didik yang kurang disiplin ketika guru mengajar burhani yaitu dengan memberikan kesempatan maju membaca burhani lebih awal, guru meminta peserta didik untuk memperhatikan apa yang sedang dibacanya, baik ketepatan dalam membaca hurufnya atau tajwidnya. Pada saat peserta didik maju membaca burhani, guru memberikan motivasi memberikan pujian kepadanya jikalau bacaannya tepat dan benar.
Konsentrasi dan perhatian peserta didik pada saat pembiasaan burhani sangat penting untuk mendapatkan hasil yang maksimal. Pemberian motivasi kepada peserta didik merupakan upaya pendekatan psikologis guru agar dapat merubah cara berpikir bahwa kesadaran dan keinginan untuk selalu belajar dan membiasakan diri untuk bertanggungjawab terhadap setiap tugas yang diberikan guru. Pemberian pujian terlihat sederhana akan tetapi dapat menimbulkan dampak motivasi pada diri peserta didik sehingga tertarikdan termotivasi untuk mengikuti membaca burhani tersebut dengan baik dan lancar.

Dari hasil pengamatan pada pelaksanaan kegiatan pembacaan burhani, guru meminta peserta didik untuk antri sebelum gilirannya membaca. Guru meminta kejujuran peserta didiknya untuk membaca sesuai dengan halaman terakhir yang sudah dibaca kemarin, kemudian guru meminta untuk membaca burhani dengan tepat. Ketika peserta didik salah dalam membaca, maka guru memperbaiki dan membenarkan bacaan mereka dengan memberi contoh yang benar dan memerintahkan peserta didiknya mengulang kembali bacaan tersebut seperti apa yang sudah dicontohkannya. Guru mencatat halaman terakhir yang sudah dibaca dan menghentikan bacaan peserta didik jika dirasa masih membutuhkan pengulangan atau terdapat banyak kesalahan dalam membaca. Langkah selanjutnya, guru memberikan contoh secara langsung kepada peserta didik berkaitan dengan tata cara membaca yang sehingga diharapkan mereka ingat akan kesalahan yang dilakukan. Selanjutnya peserta didik semakin termotivasi untuk memperbaiki cara membaca yang baik, benar dan lancar. Pengulangan dalam membaca burhani berfungsi untuk meningkatkan penguasaan dan pemahaman mendalam bagi peserta didik.

Sementara ada sebagian guru yang berpendapat bahwa strategi untuk menginternalisasikan nilai pendidikan karakter pada peserta didik juga dapat dilakukan melalui kegiatan muraja'ah. Kegiatan muraja'ah dilaksanakan pada hari senin dan rabu pukul 14.00-16.00 WIB, pelaksanaannya dilakukan bersama dalam 
satu bulan yakni pada minggu ke 2 dan ke 4, terdiri dari 3 kelas yaitu kelas 3a, 4a, dan 5a. Pada pelaksanaan muraja'ah bersama, guru memberikan point sesuai dengan kriteria benar dan ketepatan dalam hafalan pada masing-masing surat, kemudian dijumlah dan diumumkan kelas mana yang mendapatkan point paling banyak dengan penilaian dilakukan oleh 3 guru muraja'ah. Strategi yang dilakukan oleh guru melalui penggunaan metode muraja'ah adalah dengan membentuk kelompok sesuai tingkat kemampuan hafalan peserta didik, kemudian kelompok tersebut dapat berganti-ganti sesuai kemampuan hafalan peserta didik pula. Guru memberikan peringatan kepada peserta didik melalui teguran beberapa kali, jika peserta didik tidak mendengar atau tidak menghiraukan teguran guru, maka solusinya menyuruh peserta didik maju di depan kelas untuk hafalan muraja'ah terlebih dahulu. Pelaksanaan hafalan muraja'ah pada tahap apersepsi di awal pembelajaran dengan membaca surat tertentu secara bersama-sama dengan nada 1234 atau sering disebut muriqi.

Guru melakukan pembiasaan sebelum muraja'ah dimulai agar lebih terarah dan tertib. Pada saat muraja'ah kelas, guru memberikan kesempatan kepada peserta didik untuk maju menghafal muraja'ah sesuai dengan kemampuan hafalan yang akan dihafalkannya. Jika keadaan kelas tidak terkondisikan, maka guru dapat melakukan tindakan dengan memanggil nama peserta didik yang berbicara sendiri atau tidak serius dalam belajar dan memintanya agar maju menghafal muraja'ah lebih awal. Pada saat murajaah bersama, guru memberikan arahan dan aturan main berkaitan dengan pemberian point yang disesuaikan kemampuan peserta didik dalam menjawab pertanyaan darinya. Pemberian point penilaian dilakukan oleh 3 guru muraja'ah dengan harapan agar peserta didiknya termemotivasi dalam meningkatkan kemampuan hafalannya. Kemudian hasil dari total point yang didapatkan selanjutnya diakumulasikan sehingga kelas yang meraih point tertinggi akan mendapatkan hadiah dari guru. Melalui cara ini internalisasi pendidikan karakter dapat meningkatkan daya kognitif, afektif, psikomotorik dan spiritual peserta didik yang nantinya bermanfaat untuk bekal masa depan mereka.

Pendapat lain menyatakan bahwa strategi untuk menginternalisasikan nilai pendidikan karakter pada peserta didik selain melalui pembiasaan membaca burhani dan muraja'an juga dapat dilakukan dengan pembiasaan-pembiasaan sebagai berikut: (a) sholat dhuha dan dzuhur berjamaah, melalui sholat dhuha dan dzuhur berjamaah ini mental, sikap dan karakter peserta didik dapat dipantau dengan harapan peserta didik dapat merealisasikan kebiasaan tersebut dalam kehidupan sehari-hari; (b) tahfidz Al Qur'an, internalisasi pendidikan karakter pada peserta didik melalui kegiatan tahfidz Al Qur'an bukan hanya sekedar menghafal tetapi juga berinteraksi dengan Al Qur'an yaitu dengan membaca, menghafal, mentadaburi serta mengamalkannya, dan (3) baca tulis $\mathrm{Al}$ Qur'an (BTA), kegiatan baca tulis Al Qur'an juga dapat dijadikan strategi untuk mengintenalisasi nuilai pendidikan karakter kepada peserta didik. Target kegiatan BTA setiap hari adalah lebih diprioritaskan pada peserta didik yang kurang lancar dengan harapan mereka bisa terfokus untuk baca tulis Al Qur'an sehingga target yang telah direncanakan dapat terpenuhi. Berdasarkan hasil analisis dokumen bahwa BTA merupakan strategi pengenalan keterampilan membaca dan menulis Al Qur'an sejak usia dini dan menumbuhkan kecintaan serta kegemaran membaca $\mathrm{Al}$ Qur'an dengan metode burhani.

\section{b. Metode pembelajaran CTL dan pembiasaan membaca Al Qur'an dapat menangkal pengaruh kemajuan teknologi informasi dan komunikasi di 3 SD Negeri dan swasta solo raya}

Dari hasil pengamatan di MIM Tanjung Sari bahwa kemajuan teknologi informasi dan komunikasi (TIK) berpengaruh terhadap perkembangan karakter dan moral peserta didik. Terlihat akhir-akhir ini situasi terbalik dimana bukan lagi peserta didik yang menguasai perkembangan TIK, namun perkembangan TIK yang menguasai karakter mereka. Di sisi lain, dampak perkembangan TIK tidak dapat dipungkiri karena telah mampu menggeser norma dan nilai-nilai yang tertanam sejak lama dan melekat pada diri 
manusia bukan hanya terjadi pada diri peseta didik di sekolah dasar akan tetapi juga di sekolah menengah bahkan dalam masyarakat secara umum. Perkembangan penggunaan multimedia dalam menyebarkan informasi, telah berpengaruh terhadap tatanan hidup masyarakat dunia, baik sosial budaya maupun sosial psikologis. Fenomena ini terjadi disebabkan oleh semakin mudahnya seseorang dalam menyebarkan atau menerima suatu informasi serta konten-konten yang bersifat positif maupun negatif.

Sementara para guru berpendapat bahwa dari berbagai macam bentuk TIK seperti salah satunya ialah internet merupakan perpustakaan raksasa dunia. Dapat dikatakan bahwa di dalam media internet ini terdapat miliaran sumber informasi, sehingga manusia dapat menggali informasi tersebut sesuai dengan keperluan dan kebutuhannya. Arus informasi yang mengglobal berdampak pada pergeseran norma dan nilai, oleh karena itu harus diwaspadai melalui upaya penanaman nilai dan norma yang sejak dulu melekat dalam jiwa masyarakat Indonesia. Dalam hal ini guru yang memegang peranan penting untuk membelajarkan dan mengendalikan peserta didiknya sejak dini terhadap upaya pemanfaatan media informasi tersebut melalui penanaman nilai, norma dan moral sehingga dapat terwujud karakter yang baik. Adapun maksud dari arus informasi yang mengglobal hingga berdampak pada pergeseran norma dan nilai tersebut adalah semakin mudahnya siapapun membagikan dan juga menerima informasi, baik itu berupa informasi yang bersifat pribadi maupun social, informasi yang bersifat positif maupun negatif. Fenomena yang dikhawatirkan dari informasi yang mengglobal ini adalah tidak semua informasi tersebut sesuai dengan norma dan nilai yang hidup dan berkembang di Indonesia karena tidak semua informasi tersebut sesuai dengan budaya bangsa Indonesia.

Dalam pandangan lain, tentunya tidak ada seorangpun guru yang menghendaki terjadinya pergeseran karakter peserta didik dikarenakan perkembangan TIK ini, termasuk guru yang selalu berusaha mengawasi dan mengontrol perkembangan karakter peserta didiknya ditengah perkembangan TIK ini. Bagi diri seorang guru, karakter merupakan persoalan yang sangat penting mesti harus dipertahankan dan ditanamkan dalam diri peserta didik guna bekal hidup pada masa yang akan datang. Menjadi suatu keharusan bagi siapapun untuk dapat memperkuat sikap mentalnya yang positif terhadap penguasaan teknologi informasi yang terus berkembang di era globalisasi ini, karena setiap seorang dituntut agar mampu mengikuti dan menguasai serta memanfaat kemajuan teknologi itu dalam hidupnya terutama teknologi informasi dan komunikasi. Melalui teknologi informasi dan komunikasi, maka seseorang dapat lebih kreatif dan memiliki daya saing yang tinggi dalam masyarakat. Selain perkembangan TIK menyebabkan arus informasi yang mengglobal hingga masuknya kebudayaan lain, perkembangan TIK juga membawa pengaruh yang cukup signifikan bagi manusia, baik itu bagi perkembangan mentalnya maupun bagi kehidupan sosialnya. Dari kedua pengaruh tersebut sangat terasa dalam hidup setiap orang dan dapat membawa banyak perubahan pada dirinya baik perubahan positif maupun negatif bahkan dapat membawa pengaruh kepada orang lain.

\section{Pokok Temuan}

1. Strategi untuk menginternalisasikan nilai pendidikan karakter melalui metode pembelajaran CTL dan pembiasaan membaca Al Qur'an untuk menangkal pengaruh kemajuan teknologi informasi dan komunikasi dapat dilaksanakan sesuai dengan karakteristik peserta didik, materi pembelajaran, dan program sekolah. Internalisasi nilai pendidikan karakter dapat dilakukan melalui penggunaan metode pembelajaran yang berorientasi pada nilai karakter dengan beberapa tahapan teknik internalisasi sederhana seperti transformasi, transaksi nilai, dan transinternalisasi. Selain itu strategi internalisasi nilai pendidikan karakter juga dapat dilakukan dengan melaksanakan kegiatan pembiasaan yang dilaksanakan secara rutin di awal atau di akhir pembelajaran. Pembiasaan tersebut seperti pembacaan burhani, muraja'ah, sholat dhuha dan dzuhur berjamaah, tahfidz Al Qur'an, dan baca tulis Al Qur'an (data diperoleh dari MIM Gonilan). Sementara di SD Negeri Prawit I nomor 69 Surakarta 
bahwa dalam kegiatan belajar mengajar guru masih menggunakan metode ceramah. Melaui metode mengajar yang digunakan ini, dapat mengakibatkan peserta didik kurang aktif dan tidak memperhatikan guru pada saat penyampaian materi pembelajaran sehingga berdampak pada kesulitan peserta didik menerima isi materi pembelajaran.

2. Metode pembelajaran CTL dan pembiasaan membaca Al Qur'an dapat menangkal pengaruh kemajuan teknologi informasi dan komunikasi merupakan salah satu upaya guru dalam proses pembelajaran pada peserta didiknya. Dalam hal dampak pengaruh kemajuan TIK terhadap perkembangan prilaku dan karakteristik anak secara umum dapat dikatakan bahwa tidak ada seorangpun yang menginginkan pergeseran karakter anak atau peserta didikn termasuk guru. Untuk mengetahui tingkat kepahaman peserta didiknya terhadap pendidikan karakter, maka guru dapat melakukannya dengan mepraktekkan berbagai kegiatan pembiasaan yang sudah diprogramkan oleh sekolah dan kemudian menugaskan peserta didiknya untuk mempraktikkan materi yang sudah diajarkan guru. Strategi pembelajaran ini juga dapat digunakan untuk mengefektifkan dan menyukseskan pendidikan karakter di sekolah. Dengan kata lain, CTL dapat dikembangkan menjadi salah satu strategi pembelajaran berkarakter karena dalam pelaksanaanya lebih menekankan pada keterkaitan antara materi pembelajaran dengan kehidupan nyata peserta didik. Dapat dikatakan bahwa melalui pemanfaatan metode pembelajaran CTL yang divariasi dengan pembiasaan membaca Al Qur'an senantiasa dapat menangkal pengaruh kemajuan teknologi informasi dan komunikasi terutama pengaruh kurang baik terhadap perkembangan mental dan karakter peserta didik dalam kehidupan sehari-hari.

\section{KESIMPULAN}

Internalisasi nilai pendidikan karakter dapat dilakukan melalui penggunaan metode pembelajaran yang berorientasi pada nilai karakter metode pembelajaran CTL dan pembiasaan membaca Al Qur'an dengan beberapa tahapan teknik internalisasi sederhana seperti transformasi, transaksi nilai, dan transinternalisasi. Melalui ketiga tahapan sederhana tersebut, dapat dikatakan bahwa semua pelaksanaan kegiatan pengintegrasian pendidikan karakter dilingkungan sekolah dapat dilakukan melalui keteladanan, kegiatan spontan, teguran, pengkondisian lingkungan dan kegiatan rutin. Penerapan metode pembelajaran CTL dan pembiasaan membaca Al Qur'an dapat menumbuhkan respon positif dan semangat keingintahuan peserta didik terhadap pentingnya pendidikan karakter sebagai filter dari pengaruh negatif kemajuan teknologi informasi dan komunikasi. Indikatornya adalah bahwa metode pembelajaran CTL mampu mendorong peserta didik untuk dapat menerapkan hasil belajarnya dalam kehidupan nyata. Internalisasi nilai pendidikan karakter pada peserta didik memiliki makna suatu proses penyerapan nilai karakter dalam upaya melakukan perubahan pribadi mereka walaupun memerlukan waktu dan proses yang lama terutama menghadapi pengaruh kemajuan teknologi informasi dan komunikasi.

\section{Saran}

Untuk mewujudkan keberhasilan upaya internalisasi nilai pendidikan karakter pada peserta didik di tingkat sekolah dasar sangat membutuhkan perhatian dari berbagai pihak, seperti:

1. Pemerintah dalam hal ini Dinas Pendidikan dan Kebudayaan terus berupaya untuk meningkatkan ketersediaan berbagai fasilitas penunjang pembelajaran di sekolah dan melakukan pengawasan secara kontinu terhadap manajemen sekolah termasuk pemanfaatan alat-alat teknologi informasi dan komunikasi.

2. Manajemen sekolah dan guru agar terus menerus mengawasi dan mengontrol peserta didiknya terutama dalam hal pemanfaatan alat-alat teknologi informasi dan komunikasi dalam rangka menanamkan sikap mental, moral dan karakter positif kepada mereka selain melaksanakan rutinitas tugas pembelajaran. 
3. Orang tua dan lingkungan masyarakat agar senantiasa memberikan perhatian yang sungguh-sungguh pada anak ketika berada di rumah maupun saat bermain dengan teman sebayanya terutama dalam hal pemanfaatan alat-alat teknologi informasi dan komunikasi.

\section{DAFTAR PUSTAKA}

Abdul Majid, 2013. Strategi Pembelajaran. Bandung: Remaja Rosdakarya.

Ahmad Susanto, 2013. Teori Belajar dan Pembelajaran di Sekolah Dasar. Jakarta: Prenada Group.

Aris Shoimin, 2014. 68 Model Pembelajaran Inovatif Dalam Kurikulum 2013. Yogyakarta: Ar-ruzz Media.

Dharma Kesuma, M.Pd., dkk. 2011. Pendidikan Karakter: Kajian Teori dan Praktek di Sekolah. Bandung: PT. Remaja Rosdakarya.

Furqon Hidayatullah, 2010. Pendidikan Karakter: Membangun Peradaban Bangsa. Surakarta: PT. Yuma Perkasa.

Jamal Ma'mur Asnani, 2012. Buku Panduan Internalisasi: Pendidikan Karakter di Sekolah. Yogyakarta: Diva Press.

LPPM UNISRI.2013. Panduan Penelitian dan Pengabdian Pada Massyarakat. Surakarta. Universitas Slamet Riyadi.

Masnur Muslich, 2011. Pendidikan Karakter: Menjawab Tantangan Krisis Multidimensional. Jakarta: PT. Bumi Aksara.

M. Noor Rohinah, 2012. Mengembangkan Karakter Anak Secara Efektif di Sekolah dan di Rumah. Yogyakarta: PT. Pustaka Insan Madani.

Sutopo, HB, 2006, Metode Penelitian Kualitatif: Dasar Teori dan Terapannya dalam Penelitian, Surakarta: Universitas Sebelas Maret Press.

Triatmanto. 2010. "Tantangan Pendidikan Karakter di Sekolah". Dalam Cakrawala Pendidikan, Vol. 1, No. 3, 2010.

Ida Zusnani, 2012. Manajemen Pendidikan Berbasis Karakter Bangsa. Jakarta: Tugu Publisher. 